\title{
Neighborhood Security and Housing Price in Amuwo-Odofin Local Government Area of Lagos State
}

\author{
Olalekan Dimeji Bamiteko ", Oyeyemi Omodadepo Adebiyi \\ Department of Economics, Faculty of Social Sciences, University of Lagos, Akoka, Nigeria \\ Email address: \\ olalekanbamiteko@gmail.com (O. D. Bamiteko), realyemmymeji@gmail.com (O. O. Adebiyi) \\ ${ }^{*}$ Corresponding author
}

\section{To cite this article:}

Olalekan Dimeji Bamiteko, Oyeyemi Omodadepo Adebiyi. Neighborhood Security and Housing Price in Amuwo-Odofin Local Government Area of Lagos State. Journal of Business and Economic Development. Vol. 5, No. 4, 2020, pp. 214-218. doi: 10.11648/j.jbed.20200504.13

Received: October 7, 2020; Accepted: October 30, 2020; Published: November 9, 2020

\begin{abstract}
This research work identified the neighborhood security measures in Amuwo-Odofin Local Government Area (LGA). It also examined the relationship between neighborhood security measures and housing price in the LGA. The study employed primary data and surveyed 140 residents of the LGA through multistage sampling technique. Tables and Pearson's Correlation Coefficient (PPC) were used to analyze the data. The result showed that theft constitute the modal class of crime, followed by; breaking into homes, violence and robbery. Also, the used of burglary proofs, special doors and windows in houses, OPC and vigilantes have been identified to be the neighborhood security measures put in place in the LGA. From the Pearson Correlation Coefficient, houses with gatemen commands a highest price $(\mathrm{PCC}=0.71)$. While houses that are closer to the police station/security outfit $(\mathrm{PCC}=0.61)$ and houses with street's local security or vigilante $(\mathrm{PCC}=0.56)$ has higher prices. Crime rate has a negative relationship with housing price. The study concluded that the community of Amuwo-Odofin LGA put neighborhood security measures in place and these security measures have a positive relationship on price of housing in the LGA.
\end{abstract}

Keywords: Housing, Types of Crime, Neighborhood Security Measures, Housing price and Amuwo-Odofin

\section{Introduction}

Housing is an essential good and one of the basic necessities of life after food and clothing. The increasing population around the world poses a challenge on housing as a good as demand is greater than the supply. Urban centers and mega cities have more housing challenge in which Lagos is not an exemption. Logically, the increasing demand over supply leads to price increase but there are other factors or housing qualities that may raise the price of housing; one of it is proposed to be the neighborhood security. Housing consumers do not just want to live in a comfortable apartment; they want a place where their lives and properties are saved. Neighborhood security comes with a cost which is borne by the residents of the community thereby increasing the price of housing. Therefore, this study is interested in knowing if there is a relationship between price of housing and secured environment in Lagos, Nigeria.

As population increases in urban centers, ideally; the government has the responsibility to ensure safety of life and proper ties of her citizens. However, when there is government failure, the residents have to take responsibility and build up their neighborhood security. Therefore, neighborhood security is a result of government failure [34]. In 2016, the crime rate across the country was analyzed and Lagos account for $36.08 \%$ of crimes in Nigeria out of 36 states [33]. This shows the level of insecurity in the state and residents need to provide a level of security measures. By the first quarter of 2018, Lagos crime rate was drop by 55\% [32]. The reason for this sudden drop in crime rate in Lagos state by 2018 was adduced to the synergy between Community Development Association (CDA) and security agencies towards enhancing neighborhood security.

The choice of Amuwo-Odofin Local Government Area (LGA) is borne out of the fact that; crime rate was identified to be high compare to other local governments in 2018 despite the reduction in crime rate in Lagos by $55 \%$ [32]. This study seeks to know the security measures put in place in Amuwo-Odofin LGA. Putting up neighborhood security 
measures in such a community will make house consumers pay more. Housing price in this study is willingness to pay for housing commodity by the consumer; so, this study is consumer specific. Hence, this study investigates the relationship between neighborhood security and the price of housing in Lagos residential market. Section 2 contains the review of related literature while data description was presented in section 3. Section 4 shows the result and the conclusion was presented in section 5 .

\section{Review of Related Literatures}

In developed countries, studies have analyzed the relationship between different variables attached to housing, housing price and crime rate [16, 19, 27, 28]. Likewise, in Nigeria, studies have equally considered determinants of housing across various residential markets. [29] examined Ibadan residential market and identify the determinants of households' residential district preferences. Also studies like $[14,15,23,26]$ examined the effect of crime and crime rate on property value in urban area. While [1] and [13] examined patterns of violent crime in urban areas and impact of crime in Akure respectively.

Different studies have used various methodology and other variables to analyze housing price in Lagos residential market. Ajide considered the determinants of housing price and identified the characteristics of Lagos residential market through population density [2]. Studies have equally examined residential markets from different perspectives; Lagos inclusive [21, 22, 25, 5, 9, 17, 31, 6, 30]. Oluseyi examined how gated neighborhood complements the promotion of privatization of urban security in Ibadan metropolis [23]. Omojola considered the effect of crime rate on value of rental property in Ikeja, Lagos [24].

Megbolugbe used three categories of housing traits (structural, neighborhood and locational traits) to examine housing price in Jos residential market, Nigeria [18]. While, Arimah estimated housing attributes using data from both tenants and owner-occupier to identify the important determinants in the demand for housing in Ibadan, Nigeria [8]. The author identified income, household considerations, head of household occupational status and monetary value attached to the attributes being the most important determinants. The author concluded that since the coefficient of estimated variables are below unity then; the demand for housing qualities is inelastic.

Adewusi et al and Bello et al examined the property value of housing based on proximity of units to urban solid waste and dumpsite in Surulere and Ojota, Lagos Nigeria using Hedonic Pricing Model (HPM) [25, 10]. These studies established the inverse relationship between housing price and environmental disamenities. Similarly, Bello et al considered residents' willingness to pay for environmental amenities in Akure, Nigeria [11, 12]. The authors identified, distance away from refuse dump site, household income and regularity of electricity supply are key determinants that enhance households' willingness to pay for better environmental amenities. Akinjare et al examined the impact of solid waste landfills on the value of housing units in Lagos residential market [7]. The study further confirms that proximity to environmental pollution is a key determinant on the value of property in Lagos, Nigeria.

Furthermore, studies like Aluko examined location and neighborhood characteristics on housing prices in Lagos residential market $[4,5]$. Babawale et al employed HPM to examine the housing market in Ikeja, Lagos Nigeria [9]. Authors considered rental apartments, the sub-market under consideration and where plot size is unimportant. In their study, floor level was irrelevant, because the market did not cater for any price difference between flats on different floors. Oluseyi investigated the critical factors that influence the rental value of housing in Ibadan residential market, Nigeria [23]. The author used housing component such as structural and location attributes using HPM as the estimating tool to examine the trend of housing price in the area of study. The study revealed that for bungalow and detached houses in the low-density area the key factor that influence rental value is residential location while in the medium density areas burglary alarm is the major determinant of house rental price.

Studies like Umeh and Oladejo identified the housing quality traits that influenced rents in Ikeja government residential area, Lagos [31]. The study revealed that neighborhood quality and number of bedrooms influenced house prices in the area considered. Ajide used HPM to examine the impact of structural features on housing rent in Lagos, Nigeria [3]. The study revealed that consumer will prefer to pay more for desirable structural, locational and neighborhood traits in demand for housing units. This study suffers the dynamism of time where true picture of reality is lacking; the data used was based on the Lagos State Housing Survey of 2006 to analyze Lagos residential market in 2016. The Lagos residential market presents unique characteristics where both commodity and buyers are heterogeneous in nature. However, to best of author's knowledge hardly has any study considers neighborhood security and housing price in Lagos residential market using Amuwo-Odofin. This is an identified gap that this study intends to fill.

\section{Data}

Primary data was used by this study. The study area is Amuwo-Odofin LGA in Lagos State, Nigeria. This study adopts a survey method for residents of the LGA. Population of houses and households living in Amuwo-Odofin LGA is unknown; therefore, the sample size for this study is 140 . The choice for the sample size is borne out of time constraint for this study. Multistage sampling technique was engaged by this study. The method of analysis used by this study is both descriptive statistic and Pearson Correlation Coefficient. Table showed the answers of respondents on types of crime and neighborhood security measures in Amuwo-Odofin LGA. The relationship between neighborhood security and housing price was achieve using Person Correlation Coefficient. 


\section{Result}

\subsection{Crimes Experienced in Amuwo-Odofin Local Government Area}

The starting point was to find the kind of crimes experienced in the LGA. Amuwo-Odofin LGA has been known to house many government security agencies like Police posts, police stations and police commands, Ojo military cantonment, state security service, customs, immigration, prison service (Kirikiri), Nigeria Drug law enforcement Agency under a name called "Neighborhood Watch". Despite the government Neighborhood Watch, Amuwo-Odofin still remains one of the LGAs with security threats in Lagos State. From the respondents, author was able to identify the types of crime common in Amuwo-Odofin LGA and the response is shown in Table 1 below.

Table 1. Crime experienced or common Amuwo-Odofin Neighborhood.

\begin{tabular}{lll}
\hline Types of Crime experienced/ common in their neighborhood & Frequency & \% (tota \\
\hline Theft & 42 (of 140) & $30 \%($ of $100 \%)$ \\
Burglary & $15($ of 140$)$ & $10.7 \%($ of $100 \%)$ \\
Assault & 18 (of 140) & $12.9 \%($ of $100 \%)$ \\
Violence & 25 (of 140) & $17.9($ of $100 \%)$ \\
Robbery & 21 (of 140) & $15($ of $100 \%)$ \\
Breaking into homes & 33 (of 140) & $23.6($ of $100 \%)$ \\
Car theft & 5 (of 140$)$ & $3.6($ of $100 \%)$ \\
Dealing in Drugs and misused substances & 23 (of 140) & $14.3($ of $100 \%)$ \\
Kidnapping & 14 (of 140) & $10($ of $100 \%)$ \\
\hline
\end{tabular}

Source: Author's Computation (2019).

The crime with the highest frequency in the neighborhood of Amuwo-Odofin LGA is theft. $30 \%$ of the respondents attest that theft is common in the area where they reside. Next to theft is breaking into homes; about $24 \%$ of the respondents indicated that breaking into homes is common in their area of resident. Violence, assault and burglary are also common in residents in the LGA. Sales and buying of illegal drugs and misused substances have also been classified as threat to security. More than $14 \%$ of the respondents attest that this threat exists in their neighborhood. Amuwo-Odofin was reported as one of the neighborhoods where business men fled for fear of being kidnapped ${ }^{1} ; 10 \%$ of our respondents affirm that kidnapping is a crime that exists in their neighborhood [34]. Car theft is the least common in the LGA.

\subsection{Neighborhood Security Measures in Amuwo-Odofin Local Government Area}

This study also asked the respondents the measures that Amuwo-Odofin residents have taken to ensure adequate security and combat crime and the result is shown in Table 2 below:

Table 2. Security Measures in Amuwo-Odofin Community.

\begin{tabular}{lll}
\hline Security Measures & Frequency & $\%$ \\
\hline Special doors and windows & 84 (of 140) & $60($ of $100 \%)$ \\
Burglary proof & 138 (of 140$)$ & $99($ of $100 \%)$ \\
High fence/wall & 77 (of 140$)$ & $55($ of $100 \%)$ \\
Security dogs & $19($ of 140$)$ & $13.6($ of $100 \%)$ \\
Vigilantes & 62 (of 140$)$ & $44($ of $100 \%)$ \\
Odua People's Congress (OPC) & 96 (of 140$)$ & $68($ of $100 \%)$ \\
Closed-circuit television (CCTV) & 9 (of 140$)$ & $6.4($ of $100 \%)$ \\
\hline
\end{tabular}

Source: Author's Computation (2019).

Almost all the respondents have burglary proof in their

1 Vanguard Newspaper; 05/08/2018. various houses, $99 \%$ of our respondents indicates that they have burglary proof. $60 \%$ of our respondents affirm that they have special doors and windows. Both burglary proof and special doors are measures used by households to prevent the house from being accessed by thieves or robbers. Also, 55\% of the respondents have high walls and fence and about $14 \%$ have security dogs. $68 \%$ of respondents indicate that OPC helps to protect their neighborhood while $44 \%$ indicated vigilante. All these measures are privately provided either by individuals or a group of individuals pulling their resources together to provide adequate security in their neighborhood. Therefore, from the response of this survey, Amuwo-Odofin residents are taking measures to make sure that their neighborhood is secured and free from crime.

\subsection{The Relationship Between Neighborhood Security and Housing Price in Amuwo-Odofin, Local Government Area}

The result of Pearson correlation coefficient is displayed in Table 3 above. Fenced apartments and community gate have a correlation coefficient of 0.38 and 0.41 with price of housing respectively, indicating weak positive linear relationship with price of housing in Amuwo-Odofin LGA. This may imply that fenced apartment as well as community gate in the community may not attract higher rental prices. Since the correlation coefficient is weak, it may imply that apartment fence and community gate may not be the sole factor that increases willingness to pay. Also, closeness to police post or station and security outfit has a correlation coefficient of 0.61 with the price of house in the local government. This indicates a moderate and positive linear relationship between price of housing and closeness to police station or security outfit. Houses that are closer to police station/post and other security outfits command a higher price in Amuwo-Odofin LGA.

Moreover, communities with vigilante or community 
security are likely to pay higher rental prices in the LGA. This is reflected in the correlation coefficient between community security or vigilante which is 0.56 , connoting a moderately positive linear relationship between community security and housing prices in Amuwo-Odofin LGA. The presence of gateman in a house has a high positive linear relationship with housing price having a correlation coefficient of 0.71 . Obviously, houses with gatemen will possess the quality of having a well fenced apartment (this reflects in the high correlation coefficient between fence and gateman which equals 0.76 ) and a personal security. This is in turn will command a high maintenance cost that houses without gatemen, thus, reflecting in the housing prices. The correlation coefficient between housing price and crime rate is -0.56 exhibiting a negative moderate linear relationship among the variables. Crime rate in the community will likely reduce housing price. This result partly supports the works of Oluseyi (2014) and Omojola (2018) that high crime (or low security measures) brings down the rental value of house.

Table 3. Result of Pearson Correlation Coefficient.

\begin{tabular}{|c|c|c|c|c|c|c|c|}
\hline & Fence & $\begin{array}{l}\text { Community } \\
\text { gate }\end{array}$ & $\begin{array}{l}\text { Closeness to } \\
\text { police/security }\end{array}$ & $\begin{array}{l}\text { Vigilante/local } \\
\text { security }\end{array}$ & Gateman & Crime rate & Price \\
\hline Fence & 1 & 0.51 & 0.012 & 0.34 & 0.76 & -0.37 & 0.38 \\
\hline Community gate & 0.51 & 1 & -0.11 & 0.54 & 0.09 & -0.32 & 0.41 \\
\hline Vigilante/local security & 0.34 & 0.54 & -0.14 & 1 & 0.13 & -0.23 & 0.56 \\
\hline Gateman & 0.76 & 0.09 & 0.05 & 0.13 & 1 & -0.34 & 0.71 \\
\hline Crime rate & -0.37 & -0.32 & -0.37 & -0.23 & -0.34 & 1 & -0.56 \\
\hline
\end{tabular}

Source: Author's Computation (2019).

\section{Conclusion}

This study identified the neighborhood security measures in Amuwo-Odofin LGA. It also examined the relationship between neighborhood security measures and housing price in the LGA. The result showed that theft constitute the modal class of crime, followed by; breaking into homes, violence and robbery. Also, the used of burglary proofs, special doors and windows in houses, OPC and vigilantes have been identified to be the neighborhood security measure put in place in the LGA and these measures are in conformity with [20]. From the Pearson Correlation Coefficient, houses with gatemen commands a highest price $(\mathrm{PCC}=0.71)$. While houses that are closer to the police station/security outfit and houses with street's local security or vigilante has higher prices. Crime rate has a negative relationship with housing price. The study concluded that the community of AmuwoOdofin LGA put neighborhood security measures in place and these security measures have a positive relationship on price of housing in the LGA.

\section{References}

[1] Agbola, T. and Jinadu A. M. (1997). Forced eviction and forced relocation in Nigeria: the experience of those evicted from Maroko in 1990. Sage Journals Volume: 9 issue: 2, page (s): 271-288.

[2] Ajide K. B. (2011). Determinants of Residential Housing Choice in Lagos State, Nigeria: A thesis submitted to the Department of Economics, Faculty of the Social Sciences, University of Ibadan.

[3] Ajide, K. B. (2016). The Institutional Quality Impact on Remittances in the ECOWAS Sub-Region. African Development Review 28 (4); 462-481.
[4] Aluko, E. O. 2002, Housing values and determinants of housing submarkets in Nigeria, Journal of the Nigerian Institute of Town Planners, Vol. XVI, October, pp. 55-68.

[5] Aluko, O. (2011). The effects of location and neighborhood attributes on housing values in metropolitan Lagos. Ethiopian Journal of Environmental Studies and Management, 4 (2), 6982.

[6] Akinyemi, B., Afolayan, O. and Ogunji, O. (2016). Some properties of composite corn cob and sawdust particle boards. Construction and Building Materials. Materials. Volume 127, 30 November 2016, Pages 436-441.

[7] Akinjare, O. A., Ayedun, C. A., Oluwatobi, A. O., \& Iroham, O. C. (2011). Impact of sanitary landfills on urban residential property value in Lagos State, Nigeria. Journal of Sustainable Development 4(2): 48-60.

[8] Arimah, B. (1992). An empirical analysis of the demand for housing attributes in a Third World city. Land Economics, 68 (4), 366-79.

[9] Babawale, G. K., Koleoso, H. A., Otegbulu, A. C., (2012). A hedonic model for apartment rentals in Ikeja area of Lagos metropolis. Mediterr. J. Social Sci. 3 (3), 109-120.

[10] Bello, M. O. and Bello, V. A. (2007). The Influence of Consumer Behaviour on the Variables Determining Residential Property Values in Lagos, Nigeria. American Journal of Applied Sciences 4 (10): 774-778.

[11] Bello, M. O. and Bello, V. A. (2008). Willingness to Pay for Better Environmental Services: Evidence from the Nigerian Real Estate Market. Journal of African Real Estate Research, 1 (1), pp. 19-27.

[12] Bello, V. A., Ajayi, C. A., 2010. Occupants' satisfaction and rent paid for residential properties close to waste dump sites in Nigeria. J. Sustainable Dev. 3 (1), 98-103.

[13] Bello, V., 2011. "The impact of urban crime on property values in Akure, Nigeria", Paper presented at the FIG Working Week, 18-22 May. Marrakech, Morocco. 
[14] Ekpenyong, R. A. (1989). Crime Prevention: Approaches, Practices, and Evaluations. Volume: 14 issue: 2, 200-202.

[15] Fabiyi, O (2004). Gated Neighbourhoods and privatization of urban security in Ibadan metropolis. New edition (online). Ibadan: IFRA-Nigeria, 2004 (generated 20 Jun 2019) Availiable on the Internet http://books.openedition.org/ifra/456. ISBN: 9791092312027. DOI: $10.4000 /$ books.ifra456.

[16] Jargowsky, P. A., \& Park, Y. (2009). Cause or Consequence?: Suburbanization and Crime in U.S. Metropolitan Areas. Crime \& Delinquency, $55 \quad$ (1), 28-50. https://doi.org/10.1177/0011128708323630.

[17] Kemiki, O. A., Ojetunde, I. and Ayoola, A. B. (2014). The Impact of Noise and Dust level on Rental Price of Residential Tenements around Lafarge Cement Factory in Ewekoro town, Nigeria. Ethiopian Journal of Environmental Studies and Management, 7 (2), 108-116.

[18] Megbolugbe, I. F. (1989). A Hedonic Index Model: The Housing Market of Jos, Nigeria. Sage Journals. 26 (5); 486494.

[19] Norzailawati Mohd Noor*, M. Zainora Asmawi, and Alias Abdullah (2015). Sustainable Urban Regeneration: GIS and Hedonic Pricing Method in determining the value of green space in housing area Procedia - Social and Behavioral Sciences 170 (2015) 669-679.

[20] Odunjo O. O \& Odunola O. O. (2013). An Appraisal of House security Measures in Lagos, Nigeria. Architectural Research 3 (3); 21-25.

[21] Olatubara, C. O. (1996). Urban activity distribution-induced residential satisfaction model. IFE PsychologIA: An International Journal 4 (2), 81-97.

[22] Olatubara, C. O. (2003). Private sector driven housing delivery (in Nigeria): Issues, constraints, challenges and prospects. Second Annual National Workshop on Private sector Driven Housing Delivery.

[23] Oluseyi, J. O. (2014). Critical factors determining Rental Value of Residential Property in Ibadan Metropolis, Nigeria. Property Management, 32 (3), 224-240.
[24] Omojola Seun (2018) Effect of Crime rate on Residential Property Rental Value in Lagos Nigeria (A Study of Ikeja) https://www.academia.edu/36913323.

[25] Onifade, F. A. and Adewusi A. O. (2006). The effects of urban solid waste on physical environment and property transactions in Surulere Local Government Area of Lagos state. Journal of Landuse and Development Studies, 2 (1); 71-90.

[26] Otu, N. E. (2010). An Evaluation of the National Environmental Standards and Regulations Enforcement Agency (Establishment) Act. A Paper Presented at the Abia State College of Postgraduate Studies, Faculty of Law, Nigeria.

[27] Paz, P. T. (2003) "Determinants of Housing Prices in Spanish Cities" Journal of Property Investment and Finance Vol. 21, No. 2, pp. 109-135.

[28] Sampson, R. J., Morenoff, J. D. and Earls, F. (1999) Beyond Social Capital: Spatial Dynamics of Collective Efficacy for Children. American Sociological Review Vol. 64, No. 5 633660 .

[29] Sanni, L. and Akinyemi, F. (2009). Determinants of Households' Residential Districts' Preferences within Metropolitan City of Ibadan, Nigeria. Journal of Human Ecology (Delhi, 25 (2): 137-141.

[30] Umar, O. S., Abdullahi O. O., Nathaniel O. O., Simeon O. F and Samuel, A. O. (2019). Residentents' satisfaction with Public Housing in Lagos, Nigeria. Ghana journal of geography Vol 11 (1) pages 180-200.

[31] Umeh, O., and Oladejo, E. (2015). Adopting the Hedonic Price of Residential Properties' Attributes to Improve Ikeja GRA in Lagos State Nigeria Environmental Review, 5 (1) Retrievedhttp://www.erjournal.net/index.php/erjournal/article/ view $/ 8$.

[32] https://nigeria.opendataforafrica.org/data\#source=NBS-N.

[33] www.premiumtimesng.com -The 2016 National Bureau of Statistics Report.

[34] www.vanguardngr.com Vanguard newspaper on August, 2018. 